\title{
Digestibility of Ficus roxburghii, Castanopsis indica and Ficus cunia on Growing Buffalo from Western Hills of Nepal
}

\author{
Netra P. Osti ${ }^{1}$, Purna B. Chapagain ${ }^{2}$, Megh R. Tiwari ${ }^{2}$ and Chet R. Upreti ${ }^{1}$ \\ ${ }^{1}$ Animal Nutrition Division, NARC, Khumaltar, Lalitpur, Nepal <nposti@narc.gov.np> \\ ${ }^{2}$ Regional Agriculture Research Station, NARC, Lumle, Kaski, Nepal
}

\begin{abstract}
Nine buffalo calves were subjected to three fodder tree species namely; Nimaro (Ficus roxburghii), Dhalne Katus (Castanopsis indica) and Rai Khanyu (Ficus cunia) for digestibility trial during November 27 and December 3, 2005 in Regional Agricultural Research Station, Lumle, Kaski, Nepal. Animals were kept 7 days for adaptation for these fodders. Weighed amount of fodder tree leaves including twigs and small branches were fed two times a day and observation on fodder offered, refused and faeces voided were recorded daily. Chemical composition of fresh matter and faeces voided were carried out for dry matter (DM), crude protein (CP), neutral detergent fiber (NDF), acid detergent fiber (ADF), lignin, calcium (Ca) and phosphorus (P). The mean DM content and their dry matter digestibility (DMD) of these three fodder tree species were found 27.86, 46.02, 34.72, $73.21,65.93$ and 71.28 percent, respectively. Strong negative correlations $(\mathrm{r}=-0.75$ to $-0.78 ; \mathrm{p}<0.05)$ were observed between $\mathrm{Ca}$ and $\mathrm{CP}$ with fiber fraction (NDF and ADF). A weak correlation was also observed between $\mathrm{P}$ and other constituents with respect to digestibility. From the results, if there could be provision of low fiber content in dry season, the three main nutrients $(\mathrm{Ca}, \mathrm{P}$ and $\mathrm{CP}$ ) may easily be absorbed by the animals.
\end{abstract}

Key words: Buffalo, digestibility, fodder tree, nutrients

\section{INTRODUCTION}

About 39.6 percent of the total land of Nepal is covered by forest and shrub. Fodder and leaf litter from forest, fodder tree from crop lands, grasses legumes available from bunds and fallow lands, crop by products from agricultural crops are the major sources of feed for ruminant animals. Fodder trees from terrace risers and marginal lands are lopped for supplementing green fodder from December to June, which is the feed scarcity period in hills and mountain of Nepal (Sherchand and Pariyar 2002). Even though the protein contents of fodder tree leaves are moderate, the animals loose their body weight and milk production drops drastically during winter months when animals are mainly provided with fodder tree leaves and rice straw. This problems may be due to seasonal rainfall, upland areas where decrease in soil moisture, deciduous plant species particularly mid hills across the country and composition and availability of nutrients present in the plant species during moisture stress condition. 
Nutrient composition of fodder tree leaves, tree fodder, grasses and legumes were evaluated (Subba 1998), but studies on nutrient availability from these feeding resources to the animals are very limited. Review of literature shows very few fodder tree species have been studied for nutrient availability to the animals (Subba 1998). In this study, efforts have been made to find out the digestible co-efficient of nutrients of fodder tree foliage such as Nimaro (Ficus roxburghii), Rai Khanyu (Ficus cunia) and Dhalne Katus (Castanopsis indica) and side by side to point out the positive and negative relation among the constituents under fresh and digestible basis.

\section{MATERIALS AND METHODS}

Nine growing buffalo calves about one and half year age (male and female) were allotted to three treatments ie Nimaro (Ficus roxburghii), Dhalne Katus (Castanopsis indica) and Rai Khanyu (Ficus cunia) and replicated three times. Animals were kept under metabolic shed, weighed amount of fodder tree leaves including twigs and small branches were provided two times a day and experiment was lasted up to 7 days. Observations as fodder offered, refused and faeces voided were recorded daily.

Fodder and fecal samples were collected in morning and evening for 7 days experimental period. The average maximum and minimum temperature recoded in samples collection site was $20.61^{\circ} \mathrm{C}$ and $12.22^{\circ} \mathrm{C}$, respectively and the total rainfall of the site was $5833.60 \mathrm{~mm}$ and average was 5303.1 $\mathrm{mm}$ per year (Annual Report 2001). Collected tree foliage and fecal samples were dried at constant heat in hot air oven at $72^{\circ} \mathrm{C}$ for over night ( 24 hours). Dried fodder and fecal samples were ground to passes through $1 \mathrm{~mm}$ sieves in hammer mill and stored for chemical analysis.

After dry matter determination, nitrogen content was determined by the Micro-Kjheldal method (AOAC 1990). The crude protein (CP) was calculated as $\mathrm{N} \times 6.25$. Neutral detergent fiber (NDF), acid detergent fiber (ADF) and acid detergent lignin (ADL) were determined by the method developed by Van Soest et al (1991). Calcium (Ca) and phosphorus (P) were measured by titration and spectrophometry method, respectively.

One-way analysis of variance (ANOVA) was carried out to compare the chemical composition and digestibility values with species of fodder tree as the main factor by using General Linear Model (GLM) procedure (Statistix for Windows 1996). Simple correlation analysis was used to establish the relationship between the chemical constituents as fresh and digestible basis.

\section{RESULTS AND DISCUSSION}

The mean chemical constituents are presented in Table 1, there is positive and negative relationship observed among the chemical constituents (Table 2). Protein, calcium and phosphorus content in feed are very important for milk production from milking animals, fiber content in fodder tree leaves have strong negative correlation (Table 2) with these nutrients. When commencing dry season plant tend to increase fiber content in the leaves, which lead to decrease these two minerals content during the winter or dry season. 
Table 1. Chemical constituents of three different fodder tree leaves from western hills of Nepal

\begin{tabular}{lccccccc}
\hline \multirow{2}{*}{ Name of fodder } & \multicolumn{7}{c}{ Chemical constituents } \\
\cline { 2 - 8 } & DM & CP & NDF & ADF & Lignin & Ca & P \\
\hline $\begin{array}{l}\text { Ficus } \\
\text { roxburghii }\end{array}$ & 27.86 & 14.27 & 54.00 & 52.46 & 32.53 & 2.82 & 0.49 \\
$\begin{array}{l}\text { Castanopsis } \\
\text { indica }\end{array}$ & 46.02 & 11.38 & 65.13 & 64.52 & 21.82 & 0.76 & 0.23 \\
$\begin{array}{l}\text { Ficus cunia } \\
\text { Mean }\end{array}$ & 34.72 & 13.61 & 43.63 & 41.08 & 20.55 & 2.47 & 0.37 \\
\hline $\begin{array}{l}\text { DM, Dry matter. CP, Crude protein. NDF, Neutral detergent fiber. ADF, Acid detergent } \\
\text { fiber. Ca, Calcium. } P \text {, Phosphorus. }\end{array}$
\end{tabular}

Table 2. Correlations (Pearson) coefficients of different chemical constituents of three fodder tree leaves from western hills of Nepal

\begin{tabular}{lrrrrrr}
\hline & DM & CP & NDF & ADF & Lignin & Cal \\
\hline CP & 0.276 & & & & & \\
\multirow{2}{*}{ NDF } & 0.473 & & & & & \\
& -0.181 & -0.750 & & & & \\
ADF & 0.640 & 0.020 & & & & \\
& -0.173 & -0.752 & 1.000 & & & \\
Lignin & 0.656 & 0.019 & 0.000 & & & \\
& 0.197 & 0.602 & 0.076 & 0.073 & & \\
Cal & 0.612 & 0.086 & 0.846 & 0.852 & & \\
& 0.273 & 0.998 & -0.786 & -0.788 & 0.738 & \\
P & 0.477 & 0.000 & 0.012 & 0.012 & 0.023 & \\
& 0.238 & 0.775 & -0.163 & -0.166 & 0.564 & 0.453 \\
& 0.538 & 0.014 & 0.675 & 0.669 & 0.114 & 0.221 \\
\hline
\end{tabular}

Digestibility of chemical constituents present in Nimaro, Dhalne Katus and Rai Khanyu were similar (Table 3). Positive correlation was observed in digestibility of all constituents except phosphorus to other constituents. Phosphorus has weak correlation to other constituents in terms of digestibility (Table 4). This low phosphorus content in fodder tree leaves may have negative effect on absorption of nutrient present in the fodder tree leaves specially lactating animals.

Table 3. Digestibility coefficients of chemical constituents from Nimaro, Dhalne Katus and Rai Khnyu found in western hills of Nepal

\begin{tabular}{lrrrrrrr}
\hline \multirow{2}{*}{ Name of fodder } & \multicolumn{7}{c}{ Digestibility coefficient } \\
\cline { 2 - 8 } & DMD & CP & NDF & ADF & Lignin & Ca & P \\
\hline $\begin{array}{l}\text { Ficus } \\
\text { roxburghii }\end{array}$ & 73.21 & 80.22 & 74.58 & 74.55 & 74.94 & 85.34 & 74.14 \\
$\begin{array}{l}\text { Castanopsis } \\
\text { indica }\end{array}$ & 65.93 & 74.58 & 62.67 & 61.54 & 76.08 & 80.89 & 82.04 \\
Ficus cunia & 71.28 & 74.29 & 77.99 & 77.45 & 79.63 & 85.32 & 71.24 \\
\hline Mean & 70.14 & 76.36 & 71.75 & 71.18 & 76.88 & 83.85 & 75.81 \\
CV, \% & 8.21 & 5.81 & 17.61 & 19.02 & 8.28 & 3.69 & 12.74 \\
SEM & 1.92 & 1.48 & 4.21 & 4.51 & 2.12 & 1.03 & 3.21 \\
\hline
\end{tabular}


Nepal Agric. Res. J. Vol. 9, 2009

Table 4. Correlations (Pearson) coefficients of digestibility of different chemical constituents of three fodder tree species leaves from western hills of Nepal

\begin{tabular}{lllllll}
\hline & DMD & CP & NDF & ADF & Lignin & Cal \\
\hline CP & 0.837 & & & & & \\
NDF & 0.005 & & & & & \\
& 0.928 & 0.680 & & & & \\
ADF & 0.000 & 0.044 & & & & \\
& 0.929 & 0677 & 0.997 & & & \\
Lignin & 0.000 & 0.045 & 0.000 & & & \\
& 0.728 & 0.502 & 0.863 & 0.856 & & \\
Cal & 0.026 & 0.168 & 0.003 & 0.003 & & \\
& 0.910 & 0.683 & 0.855 & 0.833 & 0.598 & \\
P & 0.001 & 0.042 & 0.003 & 0.005 & 0.089 & \\
& 0.066 & 0.054 & -0.056 & 0.000 & 0.154 & -0.247 \\
& 0.866 & 0.889 & 0.887 & 0.999 & 0.693 & 0.522 \\
\hline
\end{tabular}

Fodder tree leaves contain high level of calcium $(2.20 \%)$ and low level of phosphorus $(0.25 \%)$ among 30 fodder tree species found in the hills and mountain of Nepal Osti et al (2006). Similarly, Subba 1998 analyzed over 75 tree fodder species and found 0.10 to 0.90 percent total phosphorus content and he also analyzed for calcium content ranges from $26.5 \mathrm{mmol} / \mathrm{kg}$ Bakaino (Melia azedarach) to $689 \mathrm{mmol} / \mathrm{kg}$ Teli bans (Teli bans), and most of tree fodder species found $100+$ $\mathrm{mmol} / \mathrm{kg}$ calcium content. This low level of phosphorus and negative correlation between calcium and phosphorus with fiber fraction may be the one factor for low milk production during dry season in the hills and mountain of Nepal. This finding is closely supported with the finding of Davies et al (1938) who reported that the presence of soils low in plant available phosphorus results in herbage with subnormal phosphorus content and occurrence of a dry period in each year when the plants are dry and mature and the seed is set accentuated or prolong this effect. Calcium and phosphorus are the major minerals required for proper milk formation in the body of milking animals, this low phosphorus contain in fodder tree leaves also have another possibility of binding to other nutrients like protein with phytate to form protein phosphorus complex which lead to low absorption of these nutrients in the animal body. The protein content of plant falls with phosphorus and also energy because all soluble carbohydrates ultimately non available with increase in dry matter content in dry season (Lapkin et al 1961). There is also quantitative ratio (2:1) between calcium and phosphorus required for proper functioning of milk secretion and 1.5 part of calcium there should be 1 part of phosphorus in the diet. If the ratio is narrower than 1:1 and wider than 2.5:1 there will be incidence of milk fever and other deficiency diseases appeared (Wattiaux 1994). From this finding the ratio between calcium and phosphorus is very weak. This low phosphorus contain in fodder tree leaves open the another rooms for further research in this area with respect to milk production in the hills and mountainous region.

Strong negative correlation was observed among fiber fraction (NDF and ADF) of fodder tree leaves with $\mathrm{Ca}, \mathrm{P}$ and $\mathrm{CP}$. A weak correlation was also observed between $\mathrm{P}$ and digestibility of other constituents. If there could be provision of low fiber content in dry season these three nutrients $(\mathrm{Ca}$, $\mathrm{P}$ and $\mathrm{CP}$ ) may absorbed easily by the animals. 


\section{ACKNOWLEDGMENTS}

The authors are thankful to Dr KB Karki, Soil Science Division, NARC for going through the manuscript and providing suggestion on statistical analysis. Also, thanks are due to Mr BS Shrestha of Regional Agricultural Research Station, Lumle for his help during conduction of trial and statistical analysis.

\section{REFERENCES}

Annual report 2001. Meteorological records. In: Annual report 2000/01. Agriculture Research Station, Lumle, Kaski, Nepal. Pp. 85.

AOAC. 1990. Official methods of analysis. $15^{\text {th }}$ Edition. Association of Official Analytical Chemists, Washington, DC, USA. Pp. 66-88.

Davies JG, AE Scot and JF Kennedy. 1938. The yield and composition of a Mitchell grass pasture for a period of 12 months. J. of the Council for Scientific and Industrial Research Australia 11:127-129.

Lapkin GH, DA Howard and DA Burdin. 1961. Study on production of beef from zebu cattle in East Africa. 3. The value of phosphatic supplement. J. of Agriculture Science, UK, 57:39-47.

Osti NP, CR Upreti, NP Shrestha and SB Pandey. 2006. Nutrients contents in fodder trees leaves, grasses and legumes from buffalo growing areas of Nepal. In: Proceedings of $5^{\text {th }}$ Asian Buffalo Congress, 18-22 April 2006, Naning, China. Pp. 366-371.

Sherchand L, and D Pariyar. 2002. Pasture forage and agroforestry technology and their dissemination status in Nepal. In: Proceedings of the $6^{\text {th }}$ National Outreach Workshop, NARC, Kathmandu, Nepal.

Subba DB. 1998. Chemical composition and nutritive values of feeds of East Nepal. Pakhribas Agriculture Centre, Dhankuta, Nepal.

Van Soest PJ, JD Robertson and BA Lewis. 1991. Methods for dietary fiber, neutral detergent fiber and non-starch polysaccharides in relation to animal nutrition. Journal of Dairy Science 74:3583-3597.

Wattiaux M. 1994. Nutrients in the feed. technical dairy guide, nutrition and feeding. The Babcock Institute for International Dairy Research and Development, University of Wisconsin, Madison, USA. Pp. 22-24. 